
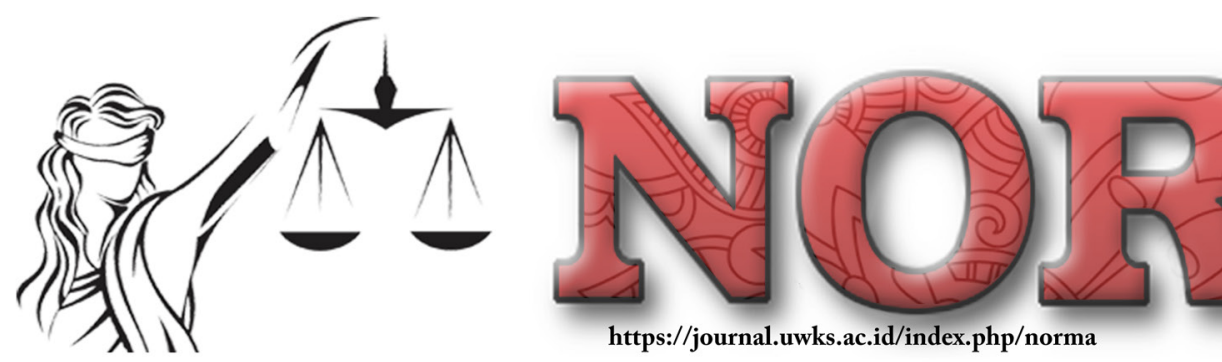

\title{
Legal Aspect for Teachers in Educating Their Students to Avoid Criminalization
}

\author{
Gendis Wulandari \\ Legal Observer \\ e-Mail: wulandari.30gendis@gmail.com
}

\begin{abstract}
:
This research, entitled legal aspect for teachers in educating their students to avoid criminalization, aims to find out and analyze how to resolve and prevent disputes for teachers and students so that teachers' actions to students and students to teachers will not be easily criminalized. This is normative legal research that will explore the contents of statutory regulations. Based on the study results, the education system in schools no longer emphasizes academic achievement on paper anymore. Developing and improving students' morality and mentality in social interactions is one crucial element that must be done. One alternative that can be used as a reference for teachers' actions towards their students, mainly the reasons teachers do such acts, is that all Teachers substitute parents in the school.
\end{abstract}

Keywords: Students, Teachers, Criminalization.

\author{
Article's History: \\ Received: \\ 3 October, 2020; \\ Received in revised form: \\ 10 February, 2021; \\ Accepted: \\ 10 February, 2021; \\ Published: \\ 10 February, 2021. \\ DOI: \\ 10.30742/nlj.v17i3.1042
}

\section{INTRODUCTION}

The obligation to provide legal protection to teachers in carrying out their professional duties is mainly placed on the government, both central and local governments. This obligation begins with providing statutory regulations ranging from Laws, Government Regulations to Regional Regulations as a legal umbrella for the government and local governments in making policies and forms of appropriate policies and following the rights that teachers must accept. ${ }^{1}$ The central government has enacted Law Number 20 of 2003 concerning the National Education System, Law Number 14 of 2005 concerning Teachers and Lecturers, Government Regulation Number 19 of 2005 concerning National Education Standards, and Government Regulation Number 74 of 2008 regarding Teachers. These laws and regulations are the primary basis or legal basis for the government in carrying out the obligation to provide legal protection for teachers. ${ }^{2}$

\footnotetext{
${ }^{1}$ Minal Ardi. (2012). Pengaruh Pemberian Hukuman Terhadap Disiplin Siswa Dalam Belajar(Penelitian eksperimen di kelas VIII Sekolah Menengah Pertama Negeri 1 Nanga Tebidah Kecamatan Kayan Hulu Kabupaten Sintang. Jurnal Eksos Vol. 8 No. 1 the Year 2012. Pontianak: Jurusan Akutansi Politeknik Negeri Pontianak, p. 61

${ }^{2}$ Ibid.
} 
Normatively, teachers have received protection, as stipulated in Article 14 letter G, and Article 39 of Law Number 14 of 2005. The protection referred to includes legal protection, professional protection, and protection of occupational safety and health. Legal protection contains acts of violence, threats, discriminatory treatment, intimidation, or unfair treatment on students, parents of students, society, bureaucracy, or other parties. So that legally, the efforts to guarantee teachers' protection have been fulfilled in the laws and regulations. However, in this case, it is still necessary to understand the law so that it can achieve justice in its implementation. With the issuance of Regulation of the Minister of Education and Culture Number 10 of 2017 concerning Protection of Educators and Education Personnel, this is a form of the government's efforts to protect teachers and education personnel in carrying out their duties. The protection obtained by teachers and education personnel includes legal protection, profession, occupational safety, and health and intellectual property rights. This Permendikbud will provide more guaranteed protection for educators and education personnel who face problems related to implementing their duties. ${ }^{3}$

The purpose of enacting the teacher law is to regulate educational interests related to the mechanism of the education system and improve the quality of education in Indonesia. Furthermore, the law is also intended to clarify educators' rights and obligations concerning their professional educators' duties.

The Teacher Law's issuance emphasizes that the teaching profession is highly valued, and its existence is guaranteed. It means that teachers are protected by a legal umbrella that is not easy to change. This law guarantees the authority, selfdevelopment, welfare, recruitment, and transfer of teachers. However, there is a deep concern concerning its implementation. Many factors will influence this law's performance, such as the implementing organization, the implementing apparatus's capacity, the level of compliance, the public budget, and the environment. The need for significant problem solving is a task that is homework for our government. In the future, the surface will no longer appear due to delayed / incomplete problem-solving. The government must learn more from experience.

\section{PROBLEM FORMULATION}

Legal Protection of Teachers for Violent Actions While Educating Their Students in School Environment

\section{RESEARCH METHOD}

This research is normative legal research with a statutory approach. The discussion will be based on regulation.

${ }^{3}$ Abdul Rahman dan Rinaldi. (2018). Perlindungan Hukum Terhadap Profesi Guru Atas Tindakan Pemberian Hukuman Terhadap Siswa. Prosiding Profesionalisme Guru Abad XXI Seminar IKA UNY. Surakarta: UNY, p. 184 


\section{DISCUSSION}

The number of cases of violence recently experienced by teachers. Motivating (PGRI) the Teachers Association of the Republic of Indonesia, the government through Kemdikbud immediately drafts the Teacher Protection Law. This law's existence is considered very important to provide protection and a sense of security for teachers so that they can focus on teaching. While waiting for the Teacher Protection Law, the government should issue a Government Regulation first to be realized more quickly. Incidents of persecution of teachers who are carrying out state duties, educating the nation's children, and improving the nation's intelligence are not maximal due to students' actions of irresponsible parents.

Teachers carry out the primary duties of teachers as professional educators. Suppose all citizens know the Teacher's responsibility to educate the nation's sons and daughters to become good citizens. In that case, everyone will support and protect teachers from protecting the teaching profession from criminalization or violence against teachers. All realize that to prepare an innovative, superior, competitive generation and has a key character lies in the Teacher. In several countries, anti-violence training in schools has been carried out a lot. Several methods and training on violence in schools. What has been done in schools in the United States, Australia, and Europe as well as several other countries includes:

1) Peer partnering/ befriending. It is part of a proportional intervention strategy through peer groups to protect, assist or look after small and vulnerable students who are vulnerable as victims of violence. Its activities are support and "lessons" to be confident, skilled in making school assignments, adaptable, and expand friendships;

2) Peer mentoring, knowing, talking, empathizing, and assisting students, the environment, and the lessons they get. Guiding students to obtain self-esteem to be confident, able to solve problems, and have meaning for others;

3) To make effective counseling and mediation by actively listening, helping to provide feedback on problems faced by students, using methods that focus on feelings, and avoid blaming;

4) Share responsibility if there is violence that involves the group, then the group must be responsible for doing something to improve attitudes, especially towards victims and their communities. Accountability is not blaming but should be focused on solving problems and not repeating them;

5) Supporting network collects, selects, and processes the latest data and information with fellow parents, teachers, students, and other parties who know about violence. Supporting networks, generally fear meeting and the use of communication technology and computers; 
6) Conduct control and communication with children. Inviting children to be able to communicate and express opinions about each other's daily problems. Management is carried out to determine the child's condition without the intention of restricting the child's freedom;

7) A cognitive, social intervention by adults \& children Together Against Violence assigns parents and adults to protect children from violence and injury by establishing a learning environment that focuses on non-aggressive physical and social skills. The birth of the sale and purchase agreement has a significant meaning, namely the seller and the buyer are bound to each other because of an agreement to exchange obligations between the parties, which later if the obligation is fulfilled, it will give birth to the rights desired by one of the parties which has indeed been used as a source of action from the beginning legal relationship.

In perspective, some actions in the school environment can be potentially violent, but this must be based on a person's motivation to take action; the intended action is either repressive or responsive. Efforts to tackle acts of violence in the school environment through the socialization of the importance of legal awareness are held not to give the impression of violence against students committed by teachers as parents in the school environment, impacting student guardians taking retaliation against the Teacher.

Based on Permendikbud Number 10 of 2017, there are four protections obtained by educators and teaching staff. The fourth includes legal protection, profession, occupational safety and health, and intellectual property rights.

1) Legal protection. Legal protection for educators (teachers) and education personnel, including protection against violence; threat; discriminatory treatment; intimidation; and no sister. Whether done by students, parents of students, society, the bureaucracy, and other parties;

2) Professional Protection. Professional protection for teachers (educators) and education personnel, including protection for:

a) Termination of employment that is not following the provisions of laws and regulations;

b) Giving improper compensation;

c) Restrictions in expressing views;

d) Harassment of the profession;

e) Other restrictions or prohibitions can hinder Educators and Education Personnel from carrying out their duties.

3) Safety and Health Protection. An educator and education personnel are obliged to receive occupational safety and health protection. This protection includes protection against risks:

a) Job security disturbances;

b) Work accidents; 
c) Fire during work;

d) Natural disasters;

e) Work environment health;

f) Other risks.

4) Protection of Intellectual Property Rights. Protection of intellectual property rights for educators and education personnel includes protecting copyright and industrial property rights.

Teachers' paradigm as parents in a school environment is if the position is not in place anymore, and authority has been misused. The peace of life has been disrupted, and decency has been threatened. ${ }^{4}$ So in its realization, several programs are implemented, including:

1) Religious Approach. The use of religious facilities in the school environment is one of the concrete programs in this service activity. The use of these places of worship aims to improve the spiritual approach for students who can take advantage of the available facilities of prayer, including the maintenance of school facilities that can develop students' disciplinary attitudes, as well as the maintenance of a climate of One God, because religious values are an essential factor to be considered. For students in deciding an action. Socialization activities in the early stages with a spiritual approach will open the door to accepting all good things in students so that it is efficient when the law is inserted into the students' souls as forming good moral values. Guidance for children in worship is considered a complement to fostering aqidah because the value of prayer obtained by children will increase confidence in the truth of their teachings or, in other terms, the higher the value of worship has, the higher the value of faith. ${ }^{5}$ Training students by forming habits can make the truth of the teachings that students believe will be concretely manifested in their behavior inside and outside the school environment. From an early age, the religious approach referred to in Islam's teachings was not when students were in high school and the equivalent, even long before at the age of 8 , they were obliged to start practicing worship. A child's obligation from the age of 8 is not a burden that can make students get pressure, but the hope is more towards preparation, training, and habituation. Because students' stress can affect the motivation to achieve, hope for students to grow and develop following their religion can certainly be realized because the laws that are enforced on children always refer to the basic framework of the formation of Law No. 35 of 2014 concerning Child Protection. The construction of students' emotional intelligence can be found through this

${ }^{4}$ Nurul Qamar, Hikmawati Mustamin. (2017). Local Wisdom Culture of Bugis Makassar in Legal Perspective. Proceeding 12 $2^{\text {th }}$ ADRI 2017 . Bogor: Perkumpulan Ahli dan Dosen Republik Indonesia (ADRI), p. 87, 2017.

${ }^{5}$ Maksum. (2012). Konsep Dasar Pembinaan Kesadaran Beragama Dalam Dunia Pendidikan Anak. Jurnal Literasi (Jurnal Ilmu pendidikan) Vol. 3 No. 1 the Year 2012. Yogyakarta: Universitas Alma Ata, p. 31-42. 
religious approach. Students who have been trained will be more patient in dealing with problems in the school environment, both to their friends and to teachers as parents in the school. Having high emotional intelligence for students is part of an educational environment's goal, academic success was strongly associated with several dimensions of emotional intelligence (intrapersonal, adaptability, and stress management abilities) assessed at the start of the academic year. ${ }^{6}$ Through this approach, it will increase the potential and open up opportunities for students to continue at a higher level of education;

2) Moral and Ethical Development Program The importance of an honest and ethical approach for students because there are still many students who do not understand the importance of maintaining morals, so they always seem indifferent and go through the educational process at school in the hope of getting a diploma to be a prerequisite for meeting various needs at a later time. It is ironic that they, as the successors and guardians of human civilization in the future, ignore the vital role of morals in taking action, for example, ignoring the principles of decency, morality, and even applicable legislation. Information published in various forms of information media has shown that human moral degradation has occurred. Improvements in moral and ethical development in the school environment need to be felt so that actions against the school environment can be minimized gradually. The effects of morals and ethics that develop through the world of education must impact the parents of students' guardians to put public trust in the world of education. Excellent students are the achievements expected by parents (both teachers and guardians). In the direction of achieving an achievement, students are quite busy. For anyone, it will feel that students seem to be actively learning, and their timewasting behavior begins to decrease. A positive impression will ward off negative issues that arise so that the problem of violence in the school environment can be minimized. Students who experience an increased understanding of the importance of their knowledge in society will soon become aware and more enthusiastic about learning and bring this positive behavior to other students. Our law mustn't be a preamble. It is early on to introduce a law to students;

3) Discipline Creation Program in Schools Discipline in the school environment must grow, not because the rampant criminalization of teaching staff and educators in schools can be a reference for reducing the level of discipline to decrease through pragmatic truth. Still, on the other hand, to enforce discipline, teachers are entitled to protection in carrying out their duties, as stated in Article 40 of Government Regulation Number 74 of 2008 concerning Teachers. Nowadays, often when entering the school environment, discipline in the school environment is still at a low stage,

${ }^{6}$ J. D. A. Parker, L. J. Summerfeldt, et al. (2004). Emotional Intelligence and Academic Success: Examining the Transition From High School to University. Personality and Individual Differences Vol. 36 No.1 the Year 2004. Amsterdam: Elsevier, p. 168 
for example in the practice of sports that are still irregular, some people are active, playing, even sitting while developing the potential of students as healthy humans also contained in Article 3 of Law No. 20/2003 on the National Education System. Discipline is not a mental attitude born from birth. Still, it is much influenced by the surrounding experiences, especially educational experiences, and disciplining students by acting within the limits of authority is not an act against the law. ${ }^{7}$ Discipline can be cultivated to be developed in various fields, including sports. For example, in a school environment, discipline is formed from active learning to make students innovative and excel in science. There is a sports discipline to make students win and excel in the field of sports. Specialization in various areas can minimize actions or actions against the law, such as the bladder, torture, and violence. Every student who excels in every field under his control must be given appreciation from all parties, in the sense of upholding the human rights of students, which are implicitly contained in the statement of the 1945 Constitution Article 29C paragraph (1), because it will build the will and develop student creativity in the learning process;

4) For teachers to use new techniques that are far from violence in educating students at school, pinching, hitting are ancient techniques in disciplining children and are no longer relevant. There are still many more effective ways than corporal punishment to deter students. The physical approach is a mixture of disciplining children and channeling emotions.

All parties do not immediately bring up cases of alleged criminal violence against teachers and child abuse against teachers. This is an educational incident, not a legal incident. Together with the DPR, the government will immediately make a Law on Teacher Protection, at least immediately issue a Government Regulation so that it can be realized more quickly.

\section{CLOSING}

\section{Conclusion}

The education system in schools no longer emphasizes academic achievement on paper anymore. Developing and improving students' morality and mentality in social interaction is one of the essential elements that must be done. In the family environment, parents are obliged to instill social values and norms in their children. There are four protections for teachers in carrying out their duties. The first is legal protection, professional protection, occupational safety and health protection, and intellectual property rights protection. The central govern $m$ ent has enacted Law Number 20 of 2003 concerning the National Education System, Law Number 14 of 2005 concerning Teachers and Lecturers, Government Regulation Number 19 of 2005

\footnotetext{
${ }^{7}$ Supreme Court Decision No. 1554 K/PID/2013. Jakarta: Mahkamah Agung Republik Indonesia.
} 
concerning National Education Standards, and Government Regulation Number 74 of 2008 regarding Teachers. These laws and regulations are the primary basis or legal basis for the government in carrying out the obligation to provide legal protection for teachers.

\section{Recommendation}

The government should pay more attention to teachers' protection as a profession because teachers' role is vital in the national education sector. One form of security that the government can take is the issuance of a Law on the Protection of Teachers so that students or parents will not criminalize all actions taken by the Teacher.

\section{REFERENCES}

Undang-Undang Dasar 1945

Undang-Undang No. 14 Tahun 2005 Tentang Guru Dan Dosen.

Undang-Undang No. 20 Tahun 2003 Tentang Sistem Pendidikan Nasional

Peraturan Pemerintah No. 74 of 2008 Tentang Guru

Peraturan Pemerintah No. 19 Tahun 2005 Tentang Standar Nasional Pendidikan

Peraturan Menteri Pendidikan dan Kebudayaan Nomor 10 Tahun 2017 Tentang Perlindungan Bagi Pendidik dan Tenaga Kependidikan

Putusan MAHKAMAH AGUNG RI No. 1554 K/PID/2013

Abdul Rahman dan Rinaldi. (2018). Perlindungan Hukum Terhadap Profesi Guru Atas Tindakan Pemberian Hukuman Terhadap Siswa. Prosiding Profesionalisme Guru Abad XXI Seminar IKA UNY. Surakarta: UNY.

Apranadyanti. (2010). Hubungan Antara Regulasi Dini Dengan Motivasi Berprestasi Pada Siswa Kelas X SMK Ibu Kartini Semarang. Thesis. Semarang: Universitas Diponegoro.

J. D. A. Parker, L. J. Summerfeldt, et al. (2004). Emotional Intelligence and Academic Success: Examining the Transition From High School to University. Personality and Individual Differences Vol. 36 No.1 the Year 2004. Amsterdam: Elsevier.

Maksum. (2012). Konsep Dasar Pembinaan Kesadaran Beragama Dalam Dunia Pendidikan Anak. Jurnal Literasi (Jurnal Ilmu pendidikan) Vol. 3 No. 1 the Year 2012. Yogyakarta: Universitas Alma Ata.

Minal Ardi. (2012). Pengaruh Pemberian Hukuman Terhadap Disiplin Siswa Dalam Belajar(Penelitian eksperimen di kelas VIII Sekolah Menengah Pertama Negeri 1 Nanga Tebidah Kecamatan Kayan Hulu Kabupaten Sintang. Jurnal Eksos Vol. 8 No. 1 the Year 2012. Pontianak: Jurusan Akutansi Politeknik Negeri Pontianak. Nurul Qamar, Hikmawati Mustamin. (2017). Local Wisdom Culture of Bugis Makassar in Legal Perspective. Proceeding 12th ADRI 2017. Bogor: Perkumpulan Ahli dan Dosen Republik Indonesia (ADRI). 